\title{
Negotiation as quasi-budgeting: the salmon catch negotiations between two world fishery powers
}

\author{
Takashi Inoguchi and Nobuharu Miyatake
}

\section{Introduction}

The study of international negotiations has been one of the most elusive topics for an empirically testable formal analysis in part because it is not always easy to obtain empirical data on the internal motives which influence the decisions and on the bargaining processes and outcomes in negotiations. ${ }^{1}$ It

Earlier versions of this paper were presented by the first author at the Conflict Resolution Seminar of Yale University, 14 January 1977, at the Annual Spring Meeting of the Japan Association of International Relations, Tokyo, 22 May 1977, and at the Joint Sessions of Workshops of the European Consortium for Political Research, Grenoble, 6-12 April 1978. The authors are grateful for the helpful comments on those earlier and other versions made by Hayward R. Alker, Jr., Mitsuo Ezaki, I. N. Galhofer-Saris, Michael Grose, Jeffrey A. Hart, Douglas A. Hibbs, Jr., Kuniko Y. Inoguchi, Harold K. Jacobson, Christer Jonsson, Jean-Christian Lambelet, Frank Langdon, Urs Luterbacher, Kinhide Mushakoji, C. M. Mason, Masatsugu Naya, Frederick L. Pryor, Bruce M. Russett, Hideo Sato, Gunnar Sjostedt, Arild Underdal, Ann Waswo, Taizo Yakushiji and Yoshinobu Yamamoto. The authors are also grateful for the useful comments and suggestions for revisions made by Robert $O$. Keohane, Wallis Ammerman, and anonymous referees. The revision of the paper was facilitated by a grant to the first author from the Japan Foundation, to which he is grateful. Needless to say, the authors alone take responsiblity for the views expressed in the paper.

' It must be noted at the outset that unlike many other studies on negotiation we are not much concerned with bargaining skill and tactics in this paper. In this sense our usage of the term negotiation is somewhat unorthodox. This point will become clear in the course of our treatment of the problem. Studies of international negotiation abound. For a survey of this field, see, for example, F. Ikle, How Nations Negotiate (New York: Harper, 1964); J. Sawyer and H. Guetzkow, "Bargaining and Negotiation in International Relations," in International Behavior: $A$ Social-Psychological Analysis, H. C. Kelman, ed. (New York: Holt, Rinehart and Winston, 1964), pp. 464-520; D. Druckman, ed., Negotiation: A Social Psychological Perspective (New

International Organization 33,2, Spring 1979

$0020-8183 / 79 / 0002-0229 \$ 01.00 / 0$

(c) by the Board of Regents of the University of Wisconsin System 
is often believed that only after those involved in the negotiations speak out and public documents are released can one understand the full scope of international negotiations. Without denying this truth, we will attempt to show that certain types of negotiations can be modeled on the basis of publicly available data. Using the data on the Soviet-Japanese negotiations for salmon catch in the Northwest Pacific for the period 1957-1977, which are available in official publications and newspapers, we will construct a simple model of the negotiations, drawing some insights from the study of budgeting. We will propose that the negotiations can be properly conceptualized as a type of quasi-budgeting in which two actors play the roles of a quasi-requester and a quasi-appropriator respectively. Like budgeting, the negotiation outcomes are reasonably predictable in the sense that regular small-scale changes in the outcomes are observed. More concretely, we will use an analogy that in the Soviet-dominated sea, Japan makes a "request" on the amount of salmon catch to the Soviet Union which in turn makes an "appropriation" on it-with both actors basing their calculations mainly on their previous experiences of quota determination.

We will use this analogy for the analysis of the Soviet-Japanese salmon catch negotiations with the belief that the same kind of analysis could be profitably applied to certain types of other issues and thus could be methodologically generalizable. Let us give some examples. First, let us try predicting the impact of the tide of the 200-mile jurisdictions on ocean management. ${ }^{2}$ Regarding exclusive economic or fishing zones, fishing states are almost inevitably drawn into bilateral (or multilateral) negotiations with coastal states, in which the former makes a sort of "request" as to the amount of fish catch allowed while the latter makes a sort of "appropriation" about it. Another pertinent example would be manganese nodule exploitation under an International Seabed Authority, a proposed global regime in the UNCLOS. ${ }^{3}$

York: Halstead, 1977); Journal of Conflict Resolution, special issue devoted to negotiation, XXI, 4 (Dec. 1977); O. R. Young, ed., Bargaining: Formal Theories of Negotiation (Urbana: University of Illinois Press, 1975); A Rapoport and A. Chammah, Prisoner's Dilemma: A Study in Conflict and Cooperation (Ann Arbor: University of Michigan Press, 1965).

${ }^{2}$ As for the transformation in ocean politics and its related topics, see the following: $J$. R. Stevenson and B. H. Oxman, "The Perspectives for the Law of the Sea Conference," American Journal of International Law 68 (1974): 1-13; "The Third United Nations Conference on the Law of the Sea: The 1974 Caracas Session," American Journal of International Law 69 (1975): 1-30; and "The Third United Nations Conference on the Law of the Sea: The 1975 Geneva Session," American Journal of International Law 69 (1975): 763-797; B. H. Oxman, "The Third United Nations Conference on the Law of the Sea: The 1976 New York Session," American Journal of International Law 71 (1977): 247-269; J. I. Swing, "Who Will Own the Oceans?" Foreign Affairs 54 (1976), 527-546; J. I. Charney, "Law of the Sea: Breaking the Ocean Deadlock," Foreign Affairs 55 (1977): 598-629; R. E. Osgood, ed., Perspectives on Ocean Policy (Washington, D.C.: U.S. Government Printing Office, 1975); A. L. Hollick and R. E. Osgood, eds., New Era of Ocean Politics (Baltimore: Johns Hopkins University Press, 1974); A. L. Hollick, "Seabeds Make Strange Politics," Foreign Policy 9 (1972-73): 148-70; and "What to Expect from a Sea Treaty," Foreign Policy 18 (1975): 68-78; E. Miles, ed., Special Issue: Restructuring Ocean Regimes, International Organization 31 (1977); and R. O. Keohane and J. S. Nye, Jr., Power and Interdependence: World Politics in Transition (Boston: Little, Brown, 1976).

${ }^{3}$ Osgood, op. cit.; Miles, op. cit.; and Keohane and Nye, op. cit. 
How much should be exploited and allocated to whom would be discussed and negotiated within the institution and within that internal bureaucratic process, a certain type of request-appropriation phenomenon can be foreseen. Although the distinction between a "requester" and an "appropriator" would be less sharp and more complicated in this case than in bilateral fishery negotiations, it would nevertheless give rise to the repeated adjustment process which is somewhat analogous to the budgetary process. A third example of its applicability might be trade negotiations on such products as automobiles, textiles, ships, or TV sets between importing and exporting countries. ${ }^{4}$ Given the increasing domestic pressure against the actuality and possibility of the rising rate of unemployment in many industrialized countries, despite the often ritual condemnation of protectionism by their governments, the process of making restrictions on the import of a certain kind of products, whether they are "voluntary restraints" or import quotas, has certain features in common with the budgetary process, even if the process of import restrictions does not take place annually. A fourth example would be the economic summits of the major advanced industrialized countries in which one of the three strong "locomotive" countries, Japan, is "requested" to reflate its domestic economy more vigorously than before and lead, together with the other two, the world economy out of recessions. ${ }^{5}$ Here again the budgetary analogy applies. Suppose the request at the summit is the 8 percent economic growth rate for Japan. Being normally very sensitive to foreign criticism, ${ }^{6}$ Japan pledges or promises or "expresses its hope" to achieve, say, 7 percent as a sort of "appropriation." It must be noted that this example represents a very loose form of a quasi-budgeting phenomenon. A fifth example is commodity negotiations between producers/exporters and consumers/importers under international commodity agreements on such commodities as coffee, tin, and cocoa. ${ }^{7}$ Although such producers/exporters and consumers/importers have equal votes as prescribed by the Havana Charter of 1948, consumers/ importers have tended to have a stronger say about the matter for the last thirty years, although producers/exporters have become more self-assertive since the early 1970s. Our sixth example is the two special "non-governmental" trade negotiations between China and Japan in 1962-1973, namely, the Liao-Takasaki and Memorandum Trade negotiations. ${ }^{8}$ In the negotiations

\footnotetext{
4 See, for example, R. N. Cooper, "Trade Policy is Foreign Policy," Foreign Policy 9 (1972): 18-36; and C. F. Bergsten, "Let's Avoid a Trade War," Foreign Policy 23 (Summer 1976): 24-31.

'See, for example, A. Watanabe, "Foreign Policy Making, Japanese Style," International Affairs 54, 1 (January 1978): 75-88.

${ }^{6}$ Ibid.

' See, for example, J. W. F. Rowe, Primary Commodities in International Trade (Cambridge, England: Cambridge University Press, 1965); L. N. Rangarajan, Commodity Conflict: The Political Economy in International Commodity Negotiations (London: Croom Helm, 1978); H. Hveem, The Political Economy of Third World Producer Associations (Oslo: Universitetsforlaget, 1978).

- C. J. Lee, Japan Faces China: Political and Economic Relations in the Post-War Era (Baltimore: Johns Hopkins University Press, 1976); and J. S. Hoadley and S. Hasegawa, "Sino-Japanese Relations 1950-1970: An Application of the Linkage Model of International Politics," International Studies Quarterly 15, 2 (June 1971): 131-157.
} 
Japan wanted to have more trade with China, which in turn used this trade relationship as leverage for influencing Japan's policy toward China and Japanese internal politics. Every year during the period in which negotiations to determine the amount of trade took place, Japan played the role of a quasi-requester and China that of a quasi-appropriator. (One year after the diplomatic normalization between them in 1972, this "non-governmental" trade relationship was abolished.)

What runs through these examples can be abstracted in order to show the potential generalizability of our framework into other issue areas. First, there is a sort of requester-appropriator relationship in which an appropriator is bound to take a requester's "demand" seriously despite an appropriator's capacity to have a strong say on the matter in question. Second, there is an institutional or quasi-institutional setting, even if it is very loosely structured, in which the matter is bilaterally (or sometimes multilaterally) discussed and/or negotiated fairly regularly and which is nearly decomposable from other elements of a larger system. ${ }^{9}$ (Here we use the term nearly decomposable perhaps a little more loosely or freely than Ando, Fisher, and Simon.) Third, a more technical but no less important requirement comes in, namely, at least one aspect of the negotiation processes and at least one aspect of the negotiation outcomes have to be revealed preferably in quantitative terms. We say "preferably" because we believe the absence of readily available quantitative data should not prevent the application of the framework from being attempted. We ought to be able to proceed case by case in this respect, using various techniques for quantification at our disposal. Here it is perhaps necessary to remember that a good grasp of the subject concerned and a little imagination and ingenuity on the part of an analyst make a difference in the "art" of quantification. ${ }^{10}$ These three requirements for the application of the quasi-budgeting framework-it is important to note-can be used as the basic clues for identifying social interactions which can be conceived of as quasi-budgeting. A more detailed, situation-specific list of conditions or requirements for the application of the quasi-budgeting framework to a particular phenomenon has to be spelled out-a task which will be attended to in our study of the Soviet-Japanese salmon catch negotiations.

It must be noted at the outset that we are aware of the fact that there is always more than one way of explaining the same phenomenon and that our

'About the concept of near decomposability, see H. A. Simon and A. Ando, "Aggregation of Variables in Dynamic Systems," Econometrica 29 (April 1961): 11-138; F. M. Fisher, "On the Cost of Approximate Specification in Simultaneous Equation," Econometrica 29 (April 1961): 139-170; F. M. Fisher and A. Ando, "Two Theorems in Ceteris Paribus in the Analysis of Dynamic Systems," American Political Science Review 61 (March 1962): 103-113; and H. A. Simon, The Science of the Artificial (Cambridge, Mass.: M.I.T. Press, 1969), Chapter 4. Most briefly, in nearly decomposable systems, "the interactions among the subsystems are weak but not negligible" and "the subsystems only interact in an aggregate form." (Simon, op. cit., 1969, pp. 100 and 107 ).

${ }^{10}$ On this point, see, for example, T. Inoguchi, "Measuring Friendship and Hostility among Communist Powers: Some Unobtrusive Measures of Esoteric Communication," Social Science Research 1 (April 1972): 79-105. 
quasi-budgeting framework is one such example. ${ }^{11}$ The salient point is, however, whether or not a particular framework is able to perform competently in explanation and/or prediction, depending on the purpose of a study.

In our study we will first present a brief history of Soviet-Japanese negotiations on the salmon catch in the Northwest Pacific. This will help readers understand why the salmon catch negotiations can be conceptualized as a sort of budgeting. Second, we will argue that negotiations of this sort can best be conceived of as quasi-budgeting. We will delineate five major features of the negotiations in order to show that the negotiations can be basically captured by a certain type of the theory of budgeting, which conceives of the process as an internal bureaucratic one. Third, after briefly discussing data sources, we will formulate and elaborate our model incorporating both aspects of negotiation processes and outcomes-in relation to budgeting-and show the estimation results for the 1957-1976 negotiations and the adjusted "predicted" values for the 1977 negotiations. Finally, we will draw our conclusions.

\section{Soviet-Japanese salmon catch negotiations}

Before tackling the problem of how to model the negotiations between the two world fishery powers, we have to look briefly at the history of fishing in the Northwest Pacific. ${ }^{12}$ Around the turn of the century Japan started developing fishing in this area. The area-rich in fish stock-was made a virtually exclusive Japanese zone by such factors as: 1) Japan's naval dominance in the Northwest Pacific after 1905 (the Japanese were victorious over Russia in the war of 1904-1905); 2) its fishing technology and skill; and 3) its need for fish protein. Russia, and later the Soviet Union, was not very

\footnotetext{
"See, for example, J. Kurth, "A Widening Gap: The Logic of American Weapons Procurement," Public Policy XIX (1971): 373-405; and P. A. Gourevitch, "International Trade, Domestic Coalitions, and Liberty: Competitive Responses to the Crisis of 1873-1896," Journal of Interdisciplinary History VIII, 3 (Autumn 1977): 281-313.

12 The following works provide the most useful and detailed historical accounts of Japanese fishing and its position in the world after World War II. Kawakami Kenzo, Sengo kokusai gyogyo seidoshi (A History of Post-World War II International Fisheries Institutions) (Tokyo: Dai Nihon Suisan Kai, 1975); G. Borgstrom, Japan's World Success in Fishing (London: Fishing News, 1964); Nihon Keizai Shimbun, Kaiyo Nihon no shumatsu (The End of Maritime Japan) (Tokyo: Nihon Keizai Shimbun, 1977); Mainichi Shimbun, Nihyaku kairi sakana senso (200-mile Fish War) (Tokyo: Mainichi Shimbun, 1977), B. Johnson and F. Langdon, "Two Hundred Mile Zones: The Politics of North Pacific Fishes," Pacific Affairs 49 (1976): 5-27, provides a good summary of the historical background of fishing in the North Pacific. Also see O. R. Young, Resource Management at the International Level: The Case of the North Pacific (New York: Nichols 1977); and L. M. Alexander, "Regional Arrangements in the Oceans," American Journal of International Law 71 (1977): 84-109. As for the day-to-day accounts of the 1977 negotiations, see major Japanese newspapers, e.g., Nihon Keizai Shimbun from December 1976 to August 1977. It may be interesting to compare the Soviet-Japanese fishery conflict of 1977 with other cases such as the Anglo-Icelandic Cod War of 1972-1973. On the Cod War, see J. Hart, The Anglo-Icelandic Cod War of 1972-1973: A Case Study of Fishery Dispute (Berkeley: Institute of International Studies, University of California, 1976).
} 
active in fishing in the area, although there were some fishery disputes between the two countries, which prompted them to conclude a fishery agreement in the 1920s. In 1945, however, Japan's dominance-both naval and fishery-in the area came to an end. The Allied Occupation Forces set up the so-called MacArthur Line beyond which Japanese merchant ships and fishing boats were prohibited. The neighboring countries-including the Soviet Union, South Korea, China, and the United States-drew lines to prevent Japanese fishing boats from operating within certain zones in an attempt to counteract the renewed fishery expansion of Japan, which had been expected to follow its independence in 1952 and was subsequently confirmed. They were led to make renewed restrictions on Japanese fishing in their coastal areas. Two consequences derived partially from these regulations and restrictions. First, driven out of much of what was considered to be its traditional fishing areas, Japan established new fishing areas all over the world, only to achieve world dominance in fishing. Second, bilateral or multilateral fishery arrangements were set up to minimize fishery disputes. Because Soviet-Japanese fishery disputes in the Northwest Pacific in 1952-1956 were very serious and salient, the two countries arranged the Joint Soviet-Japanese Fisheries Commission in the Northwest Pacific. This was prescribed in the Soviet-Japanese Northwest Pacific Fisheries Convention, concluded in May 1956, prior to the diplomatic normalization between Japan and the Soviet Union which was signed in December 1956. (The Convention became effective at the time of the diplomatic normalization.) Newspaper coverage in Japan on the annual fishery negotiations prescribed in the Convention has been considerable since 1957 , indicating that the fishery negotiations have been a pertinent issue in Soviet-Japanese relations.

The Commission was to be composed of three members from each country and aided by a large number of specialists. The Convention prescribed an initial ten-year period in which neither party could abrogate the treaty and thereafter only if one-year advance notice had been given. The Convention applied to the entire area of the Northwest Pacific, roughly west of $175^{\circ}$ west longitude, and regulated anadromous species like salmon and ocean trout, demersal species like pollack, and surface-feeding species like herring. In addition to the Convention of 1956, two separate agreements were drawn up between Japan and the Soviet Union for the regulation of fishing for shellfish, called tsubu in Japan, and crabs. (There is also a non-governmental agreement to regulate the Japanese seaweed catch around the disputed Southern Kurile Islands.) The Commission was to convene every year in the spring for negotiations to determine the modes of fishing in the area before the fishing season began. When the Commission could not reach consensus, negotiations dragged on into the fishing season itself. This phenomenon was used tactically at one time or another by the Soviet Union when it wanted Japan to accept without protest the former's "appropriation" in light of the daily decreasing salmon stock within the fishing zone. (Salmon and ocean trout climb up from the ocean to Soviet domestic rivers in late spring and summer every year, so 
that it is pointless to attempt to get a high quota while salmon stock is diminishing.)

The explicitly stated goal of the 1956 convention was to attain the "maximum sustainable productivity" (in the Japanese text) or "the maximum sustainable fish catch" (in the Russian text). However two features of this fishery regime were in evidence in actual practice: 1) joint preservation and exploitation of the fisheries on the basis of the maximum sustainable yield; and 2) the assertion of hegemonial coastal state's rights on the adjacent sea. The latter aspect received gradually more emphasis in the course of introducing various regulations such as a decrease in the number of factory ships and fishing boats and a decrease in the number of fishing days, as well as a gradual increase in fishing ban areas and fishing holiday areas in the Northwest Pacific. (Most of the Okhotsk Sea was off limits by the mid-1960s.) By 1977 the latter characteristic had been further emphasized. After the stampede of the developed countries (i.e. the United States, Canada, and the EEC) to set up a unilateral claim to 200-mile exclusive economic or fishing zones in 1976, the Soviet Union decided to defend its self-interest late in 1976 by taking similar action. In reaction, Japan too established its 200 -mile boundaries in spring 1977 when heated and prolonged negotiations were being held to counter the Soviet claim on the disputed Southern Kurile Islands, now made explicit by the Soviet 200-mile declaration of 1976. Then the Soviet Union gave a one-year advance notice to Japan in spring 1977 that it would abrogate the Convention of 1956. This was an attempt to force Japan to become more "practical and business-like" and to concentrate on fishery issues, rather than highlighting territorial issues about which the Soviet Union made it crystal clear that it would never give an inch. Subsequently, in 1977, a substantial portion of the Northwest Pacific fell under the Soviet 200-mile exclusive zones, where the Soviet Union came to wield its power far more freely than before. The Soviet Union and Japan were among the few countries to have persistently resisted the introduction of the 200-mile limits in the UNCLOS before 1974 and 1977 respectively. It was in their best interests to keep international law basically intact as it had been practiced for centuries. However, they reversed their positions on ocean order in 1976-77 in order to defend their self-interests in a somewhat adverse situation. In 1978 negotiations took place under a new agreement in which far more areas were banned to Japanese fishermen, although the Soviet Union has continued to accommodate Japanese salmon fishing, albeit with stricter regulations.

\section{Negotiation as quasi-budgeting}

Having briefly described the context in which the Soviet-Japanese salmon catch negotiations were held for the last twenty years, we are now in a position to conceptualize the negotiations as quasi-budgeting. There are five major characteristics which are outstanding in the negotiations. 
First, there is an asymmetry of commitment between Japan and the Soviet Union which can be approximately viewed as the relationship between a requester and an appropriator in budgeting. The Soviet Union has both the desire and capability to control the Northwest Pacific area and its resources, whereas the Japanese commitment has tended to focus on fishery issues, avoiding potentially or actually explosive issues such as security, territory, and the "China" factors. Japan and the Soviet Union both see each other as a potential enemy, and there have been mutually contradictory claims over four small islands in the southern part of the Kurile Islands since 1945. The Sino-Soviet conflict since the early 1960 s has complicated these two issues. It was Mao who "encouraged" the Japanese territorial claim against the Soviet Union in mid-1960s. ${ }^{13}$ Furthermore, the Japanese catch quota is discussed in the negotiations, whereas the Soviet catch quota is presented by the Soviet Union and is almost automatically approved by the Commission. Thus determining the Japanese catch represents a relationship between Japan and the Soviet Union similar to that between a requester and an appropriator in budgeting.

Second, there is the continuity and repetition of the organizational task (i.e. the annual definition of the maximum sustainable yield), the principle to which both Japan and the Soviet Union committed themselves in the 1956 Convention. As in budgeting, the same organizational task is carried out anew each year.

Third, the negotiations entail a great number of technical and professional aspects as evidenced by the predominant and preeminent presence of technocrats, bureaucrats, and specialists. The negotiations deal with highly technical and practical matters traditionally conceived within the confines of "low politics" which, when not politicized, are best handled by professionals. This aspect is similar to budgeting in which most of the hard work is handled by bureaucrats.

Fourth, there is relative independence in decision making. Legally speaking, the Soviet-Japanese Fishery Commission had the capacity to amend the Convention of 1956 without necessarily referring to the respective home governments, unlike most fishery agreements now existing in other parts of the world. It is again like budgeting in which the Bureau of Budget, the Ministry of Finance in the case of Japan, or the Office of Management and Budget in

\footnotetext{
${ }^{13}$ As for Soviet-Japanese relations, see D. C. Hellman, Japanese Foreign Policy and Domestic Politics: The Peace Agreement with the Soviet Union (Berkeley: University of California Press, 1969); S. Vishwanathan, Normalization of Japanese-Soviet Relations, 1945-1970 (Tallahassee, Florida: The Diplomatic Press, 1973); Y. C. Kim, The Soviet-Japanese Relations: Interactions of Politics, Economics and National Security, The Washington Papers No. 21 (Beverly Hills: Sage, 1974); V. N. Berezin, Kurs na dobrososedstvo i sotrudnichestvo $i$ ego protivniki: iz istorii normalizatsii otnoshenii SSSR s poslevoennyi Iaponiei (The Course of Friendship and Cooperation and Its Enemies: From the History of the Normalization of the USSR's Relationship with Post-War Japan) (Moscow: Izdatel'stvo 'Mezhdunarodnoe Otnoshenie' 1977). As for Mao's reference to the Kurile Islands, see C. J. Lee, op. cit., p. 67.
} 
the case of the United States have relative independence in decision making, although the final appropriation is made in parliament or congress.

Fifth, the members of the Commission remained relatively stable and fixed for many years. This fact created something similar to a sense of community, which was further enhanced by the salience of the above-mentioned technical and professional aspects of the Commission's negotiations. In budgeting, the Bureau of Budget or the O.M.B. maintain their own sense of community and even their ideology for long periods of time. ${ }^{14}$ The Commission was not as cohesive as those offices but this feature was shared.

If we look at the structural components of the Soviet-Japanese salmon catch negotiations in more abstract terms, the latter four components, when taken together, can be seen as approximating the above-mentioned second condition for the quasi-budgeting framework, namely, that there is an institutional or quasi-institutional setting in which the matter concerned is bilaterally (or sometimes multilaterally) discussed and/or negotiated repeatedly and which is nearly decomposable. In other words, the negotiations become an "encapsulated conflict," 15 to use one of Etzioni's concepts. The world's two largest fishery powers found a mutual interest in the regional fishery regime called the Soviet-Japanese Fisheries Commission. Political conflicts were thus successfully internalized and most of the time the negotiations took on a routine ritual aspect.

In order to make clearer how two entirely different things, namely, negotiation and budgeting, can be related to each other, it is necessary to indicate briefly how we get suggestions from two budgeting theories. The first is the theory of incrementalism. It states that budgeting follows an incrementalism by which the budget of one year is the sum of that of the previous year and some relatively stable increment. Budgeting is conceived of as an internal bureaucratic process rather than as an externally determined event. ${ }^{16}$ In our research, we were struck by the fact that the negotiators' point of reference always seemed to be the previous salmon catch or the previous allowance. The mode of basing calculations on recent past experiences is essential to these negotiations, and we will use this analogy in our equation-building enterprise. The second budgeting theory we considered is that of action-reaction, which states that the reaction to action by an adversary determines budgeting. This theory conceptualizes budgeting as an

14 As for Japanese budgeting, see John C. Cambell, Contemporary Japanese Budget Politics (Berkeley: University of California Press, 1977). As for American budgeting, see, for example, A. Wildavsky, The Politics of the Budgetary Process (Boston: Little, Brown, 1964).

${ }^{13}$ A. Etzioni, The Active Society (New York: Free Press, 1968).

${ }^{16}$ A. Wildavsky, op. cit.; O. A. Davis, M. A. H. Dempster, and A. Wildavsky, "A Theory of the Budgetary Process," American Political Science Review 60 (1966): 529-547; R. M. Cyert and J. G. March, A Behavioral Theory of the Firm (Englewood Cliffs, New Jersey: Prentice-Hall, 1962); J. P. Crecine, Governmental Problem-Solving: A Computer Simulation of Municipal Budgeting (Chicago: Rand McNally, 1969); F. W. Hoole, Politics and Budgeting in the World Health Organization (Bloomington, Indiana: Indiana University Press, 1977). 
outcome determined largely by the interactions of international adversaries. ${ }^{17}$ In our research, not only the incremental aspect of the negotiations is striking, but the interactional aspect as well. The latter aspect seems to be more salient to the behavior of Soviet negotiators, who punish the Japanese for overfishing and at the same time try to preserve the overall salmon stock in the Northwest Pacific on the basis of a stricter notion of the maximum sustainable yield.

Since this study deals with negotiations, but not with budgeting as it is normally conceived, we will not be constrained by these theories any more than is necessary and useful for our model construction. Thus, for instance, we will not exclude factors exogenous to the negotiations in our equation-building enterprise. We will get hints and insights from these theories, especially from the first one, without being straitjacketed by them. It is not our purpose to conduct a "crucial test" of these and other theories. ${ }^{18}$

\section{Empirical analysis}

Having presented our basic approach, we are now in a position to substantiate it empirically. Before going into an empirical analysis, however, we shall briefly discuss data sources.

\section{Data sources}

Official publications and newspapers are used as the data sources for this study. Neither extensive nor intensive interviewing with those involved in the

17 L. E. Richardson, Arms and Insecurity (Chicago: Quadrangle Books, 1960); M. C. McGuire, Secrecy and the Arms Race (Cambridge, Massachusetts: Harvard University Press, 1965); T. L. Saaty, Mathematical Models of Arms Control and Disarmament (New York: Wiley, 1968); P. Smoker, "The Arms Race as an Open and Closed System," Peace Research Society Papers 7 (1967); 41-62; M. Wolfson, "A Mathematical Model of the Cold War," Peace Research Society Papers 9 (1968): 107-123; J. V. Gillespie, D. A. Zinnes, G. S. Tahin, P. A. Schrodt, and R. M. Rubinson, "An Optimal Control Model of Arms Race," American Political Science Review 71 (1977): 225-244; J. V. Gillespie and D. A. Zinnes, "Embedded Games Analysis and International Conflict Model," Behavioral Science 22 (1977): 22-31; D. L. Brito, "A Dynamic Model of an Armaments Race," International Economic Review 13 (1972): 357-375; W. H. Baugh, "Response to Sudden Shifts in a Two-Nation Arms Race," Behavioral Science 22 (1977): 69-86; W. H. Baugh, "Transient-Response Analysis of Richardson-Type Arms Race Models," in Mathematical Systems in International Relations Research, J. V. Gillespie and D. A. Zinnes, eds., (New York: Praeger, 1977), pp. 221-263; U. Luterbacher, Dimensions historiques des modeles dynamiques de conflit: application aux processus de course aux armements, 1900-1965 (Leiden: Sijthoff, 1974); N. Choucri and R. C. North, Nations in Conflict: National Growth and International Violence (San Francisco: Freeman, 1975).

${ }^{18}$ As for a "crucial test," see J. R. Platt, "Strong Inference," in The Step to Man (New York: Wiley, 1966), pp. 19-36. It is interesting to see that Ostrom has recently tested a Richardson type arms race model and a Davis, Dempster, and Wildavsky type organizational politics model as applied to U.S. defense budgeting, with indistinguishable, indeterminate results. This fact might indicate the necessity for a more careful conceptual examination before the "crucial test." See C. W. Ostrom, Jr., "Evaluating Alternative Politics Model: An Empirical Test between an Arms Race Model and Organizational Politics Model," Journal of Conflict Resolution 21 (1977): 215-266. 
negotiations was possible. Soviet elites were, needless to say, not accessible. Furthermore, Japanese bureaucrats, while accessible, were either quite tight-lipped or very inarticulate about the negotiations. Perhaps this was intentional, due in part to the fact that the difficult 1977 negotiations were taking place when the first author of this paper interviewed a number of them. Thus, less was learned from the negotiators than can be found in newspaper accounts. Controlled leaks from "reliable sources" to newspapers is not uncommon in Japan. ${ }^{19}$ This fact enables us to safely rely on newspapers for some of our data sources.

The initial commitment to incorporate into the model both the process and outcome of the negotiations led us to investigate how one aspect of the outcome (i.e. the agreed quota for the Japanese salmon catch) was arrived at. For this purpose the initial proposals of Japan and the Soviet Union for the Japanese salmon catch, which are reported in the Nihon Keizai Shimbun (Japan Economic Newspaper) have been chosen. ${ }^{20}$ The Nihon Keizai Shimbun has been carefully read for the period from December to July 1957-1977, for the figures for the initial proposals. Checking these figures against those given by the Fishery Agency of the Government of Japan has resulted in the following observations: 1) the figures reported in Japanese newspapers are strikingly accurate due to the government's controlled leaks; 2 ) there are a few instances in which some small divergences are found on the order of 100 to 1,000 metric tons when proposals range from 50,000 to 170,000 metric tons; and 3) due to an official regulation that the Fishery Agency not make official documents public until three years after their publication for internal bureaucratic circulation, we have opted to use the figures as reported in the Nihon Keizai Shimbun to ensure the uniformity of data sources. Besides the initial catch proposals, we have at our disposal the agreed quota for the Japanese catch, the actual catch figure of both countries, and the planned catch figure of the Soviet Union, all of which are reported in an official publication of the Government of Japan, On the Soviet-Japanese Fisheries Commission. ${ }^{21}$ The consumer price of salmon in the Tokyo area is also reported in an official publication, The Annual Report of the Consumer Price Index. ${ }^{22}$ Full use of these data enables us to build a model showing how the initial proposals are transformed into the agreed quota. ${ }^{23}$

\footnotetext{
"See, for instance, N. B. Thayer, "Competition and Conformity: An Inquiry into the Structure of the Japanese Newspapers," in E. F. Vogel, ed., Modern Japanese Organization and Decision-Making (Berkeley: University of California Press, 1975), pp. 284-303.

${ }^{20}$ The Nihon Keizai Shimbun is a Japanese Wall Street Journal or Financial Times. The coverage of the negotiations does not differ very much from one newspaper to another among big newspapers in Japan. However, the Nihon Keizai Shimbun seems to provide a most dispassionate reporting about them.

${ }^{21}$ Nisso gyogyo iinkai ni tsuite (Tokyo: Fishery Agency, Government of Japan, 1976).

22 Shohisha bukka shisu nempo (Tokyo: Bureau of Statistics, Office of Prime Minister, Government of Japan).

${ }^{23}$ The data set may be obtained from the authors upon request.
} 
Four single-equation models

A structural equation model is used to explain how the agreed quota is causally related to other variables endogenous or exogenous to the negotiations. Four single equation models will be separately constructed and no attempt will be made to construct a simultaneous equations model. The four equations attempt to explain the Japanese initial proposal for the Japanese catch of the year concerned (JIP), the Soviet initial proposal for the Japanese catch of the year concerned (SIP), the agreed quota for the Japanese catch of the year concerned (AQJC), and the Soviet catch plan of the year concerned (SP).

Before going into the description, elaboration, and justification of the model, it is helpful to make the following observations about the agreed quota. (See Figures 1 and 2.) First, the quota decreased steadily as a trend, if not year by year. Second, it is generally the case that in the odd-numbered years which happen to be good harvest years because of the biological cycle of ocean trout, a higher quota is allotted than in the even-numbered years which happen to be poor harvest years. This is why we find a two-year time lag in several variables in some of the following equations. Third, there was a sharp jump between 1961 and 1962, which resulted in a drastic increase in the quota for the salmon catch. In other words, after 1962, much of the previously unregulated salmon catch came under regulation. Fourth, the first few years showed some irregularities which may be viewed as an organizational learning or trial-and-error process.

\section{JIP equation}

We have the following JIP equation:

$\mathrm{JIP}_{t}=\mathrm{a}_{1}+\mathrm{b}_{11} \mathrm{AQPR}_{t}+\mathrm{e}_{1 t}$

where

$\mathrm{AQPR}_{t}=\mathrm{AQJC}_{t-2} \cdot \mathrm{PRSM}_{t-1}$;

$\mathrm{JIP}_{t}:$ the Japanese initial proposal for year $t$;

$\mathrm{AQJC}_{t-2}$ : the agreed quota for the Japanese catch two years earlier;

PRSM $_{t-1}$ : the consumer price of salmon per unit in Tokyo one year earlier;

$a_{1}:$ a constant term;

$\mathrm{e}_{1:}:$ an error term;

$b_{11}$ is anticipated to be negative.

The JIP equation has only one explanatory variable, i.e., AQPR. AQPR, is the multiplicative term of $\mathrm{AQJC}_{t-2}$ and $\mathrm{PRSM}_{t-1}$. That is to say, the agreed quota for the Japanese catch two years earlier multiplied by the consumer price of salmon per unit in Tokyo one year earlier. AQPR can be approximated to be the expected amount of Japan's salmon catch sales in the year concerned. We hypothesize that the expected market sale of salmon 
determines the Japanese initial proposal negatively. In other words, if the expected sale in yen is large (small), the Japanese initial proposal in terms of metric tons can decrease (increase). Some may think that a high price for salmon would lead to a higher Japanese initial proposal, since it would indicate that more fish could be sold at a remunerative price. However, Japanese negotiators cannot escape from the decreasing trend of salmon stock and thus from the Japanese catch quota. Given the strict Soviet annual "appropriation," they seem to be aware that a high initial proposal would not help increase the quota very much anyway, and this is based on their early experiences with Soviet negotiators in the late 1950s. In other words, when the elasticity of supply is very small and when the growth of supply is negative as a trend, if not year by year, Japanese negotiators can only console themselves with the thought that the expected amount of salmon sales increases, if not its catch quota, because price goes up when supply decreases. Besides the market mechanism which pushes up its price when supply falls, the Japanese have strong fishery oligopolists who can benefit even by resorting to contrived shortages. (What is worse, Japanese negotiators seem to be fully aware of an important loophole, namely, that Japanese fishermen tend to overfish salmon stock "secretly" beyond the agreed quota of the Japanese catch.) For these reasons, we anticipate $b_{11}$ to be negative. In this equation we are basically following the first theory of budgeting, although JIP, is formulated to be determined neither by $\mathrm{AQJC}^{t-2}$ nor by $\mathrm{JIP}_{t-2}$ but by $\mathrm{AQJC}_{t-2} \cdot \mathrm{PRSM}_{t-1}$. Since we are not straitjacketed by the first theory of budgeting, the exogenous variable, PRSM $_{t-1}$, comes into this equation.

\section{SIP equation}

We have the following SIP equation:
$\operatorname{SIP}_{t}=\mathrm{a}_{2}+\mathrm{b}_{21} \mathrm{AQJC}_{t-2}+\mathrm{b}_{22} \mathrm{TC}_{t-2}+\mathrm{e}_{2 t}$
where
$\mathrm{TC}_{\mathrm{t}-2}=\mathrm{JC}_{t-2}+\mathrm{SC}_{t-2}$
SIP,: the Soviet initial proposal for year $t$;
$\mathrm{AQJC}_{1-2}$ : the agreed quota for the Japanese catch two years earlier;
$\mathrm{TC}_{t-2}:$ the total catch two years earlier;
$\mathrm{JC}_{t-2}:$ the Japanese catch two years earlier;
$\mathrm{SC}_{t-2}$ : the Soviet catch two years earlier;
$\mathrm{a}_{2}$ : a constant term;
$\mathrm{e}_{2 \mathrm{r}}:$ an error term;
$b_{21}$ is anticipated to be positive and $b_{22}$ negative.

There are two variables to explain the Soviet initial proposal. One is the agreed quota for the Japanese catch two years earlier. The other is the sum of both the Japanese catch and Soviet catch two years earlier. The former variable has a positive relationship vis à vis the Soviet initial proposal, while the latter variable has a negative relationship vis à vis the Soviet initial 


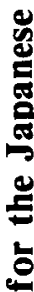

ษั

$\stackrel{2}{3}$

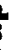

刃ू

สำ

g

홍

응

要这

홍요응

몽

尝

는

品

空

톨

क

를

훙

త్

8

토

동

5

은

능 흔

氙

\&̊용

음옹

종

를

造

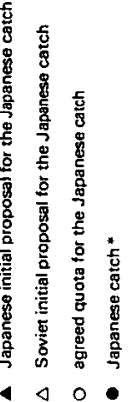

$\Xi$

ธั

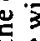

폰

氙

过

त

¿

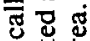

可

司买

可

可

90

品

兰 元

$\Xi$ 它

$=$

政

Ð

47

แू。

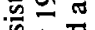

它芯

든

5े

T.

政3

a

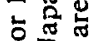

$\stackrel{\infty}{\infty}$

ธิ

茗

象

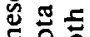

ㅎํㅇㅇㅇ

Iㅁ

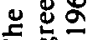

F

* 


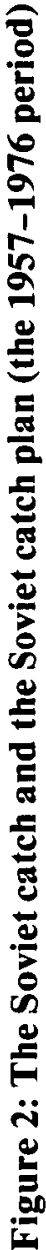
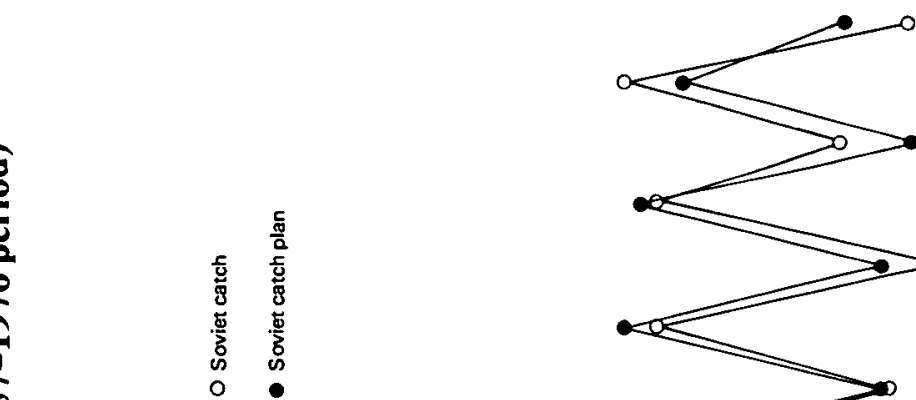

$\Re$

n

居

$\stackrel{\$}{\$}$
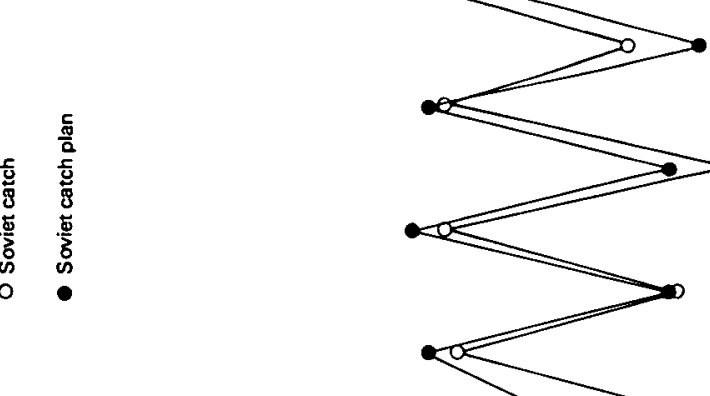

(n)

b

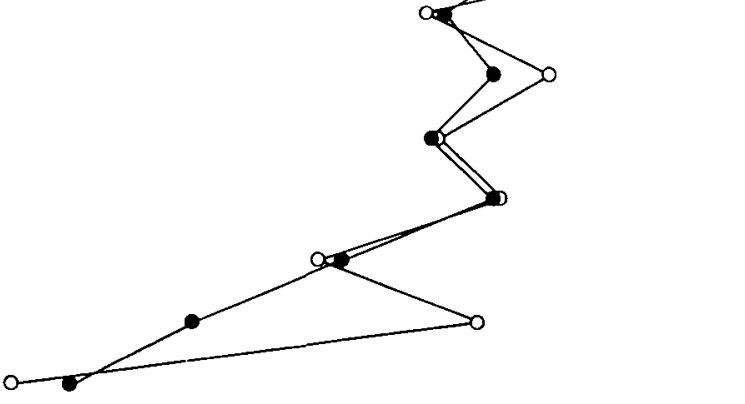


proposal. In other words, when the agreed quota for the Japanese catch two years before is large, then the Soviet initial proposal is large; and when the total catch is large, then the Soviet initial proposal tends to be small. The latter relationship makes sense when we take into account the fact that the Soviet Union has been more strongly concerned than Japan has with the depletion of fishery resources in the Northwest Pacific which the Soviet Union tends to see as quasi-territorial waters. In this equation we are getting insights from the

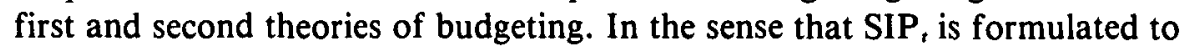
be partially determined by $\mathrm{AQJC}_{t-2}$, if not by $\mathrm{SIP}_{\mathrm{s}-2}$, the equation is basically following the first theory. But in the sense that SIP, is formulated to be partially determined-and determined negatively_by $\mathrm{TC}_{t-2}$, the equation can be illuminated by the second theory which sees interaction between parties as very important.

\section{AQJC equation}

We have the following $A Q J C$ equation:

$\mathrm{AQJC}_{t}=\mathrm{a}_{3}+\mathrm{b}_{31} \mathrm{JIP}_{\mathrm{t}}+\mathrm{b}_{32} \mathrm{SIP}_{\mathrm{t}}+\mathrm{e}_{3 t}$ where

$\mathrm{AQJC}_{i}$ : the agreed quota for the Japanese catch for year $\mathrm{t}$;

JIP.: the Japanese initial proposal for year $t$;

SIP.: the Soviet initial proposal for year $t$;

$a_{3}:$ a constant term;

$\mathrm{e}_{3}:$ an error term;

$b_{31}$ is anticipated to be positive and $b_{32}$ positive.

The AQJC equation has two independent variables. One is the Japanese initial proposal. The other is the Soviet initial proposal. Both $b_{31}$ and $b_{32}$ are naturally anticipated to be positive. In the equation we are simply stating that $\mathrm{AQJC}$, is determined by the initial proposals of both countries.

\section{SP equation}

We have the following equation:

$\mathrm{SP}_{t}=\mathrm{a}_{4}+\mathrm{b}_{41} \mathrm{SC}_{t-2}+\mathrm{b}_{42}$ DJCSC $_{t-2}+\mathrm{e}_{4 t}$

where

$\mathrm{DJCSC}_{t-2}=\mathrm{JC}_{\mathrm{t}-2}-\mathrm{SC}_{t-2}$ for the odd-numbered years

$$
=0 \quad \text { for the even-numbered years }
$$

$\mathrm{SP}_{t}$ : the Soviet plan for year $\mathrm{t}$;

$\mathrm{SC}_{1-2}$ : the Soviet catch two years earlier;

$\operatorname{DJCSC}_{t-2}$ : the difference between the Japanese catch two years earlier and the Soviet catch two years earlier in the odd-numbered years;

$\mathrm{JC}_{t-2}:$ the Japanese catch two years earlier;

$\mathrm{a}_{4}$ : a constant term;

$\mathrm{e}_{4 r}:$ an error term;

$b_{41}$ is anticipated to be positive and $b_{42}$ positive. 
The SP equation has two explanatory variables. One is the Soviet catch two years before. Thus $b_{41}$ is naturally anticipated to be positive. The second variable is the difference between the Japanese catch two years earlier and the Soviet catch two years earlier for the odd-numbered years which happen to be fishing harvest years due to the two-year biological cycle of ocean trout. It is important to emphasize that the second variable applies only to the oddnumbered years. The Soviet Union, more strongly concerned about fishery resource depletion than Japan, seems to attempt to achieve parity in the oddnumbered years, i.e. good harvest years, while in the even-numbered years, it seems to be satisfied with around one half of the Japanese catch. Thus, $b_{42}$ is anticipated to be positive. In the equation we are getting insights from both the first and second theories. In the sense that $\mathrm{SP}_{t}$ is formulated to be partially determined by $\mathrm{SC}_{t-2}$, if not by $\mathrm{SP}_{t-2}$, we are following the first theory. On the other hand, when we formulate that $\mathrm{SP}_{t}$ is partially determined by $\mathrm{DJCSC}_{i-2}$, we are seeing an interactive term which is very important.

\section{Estimation results}

Tables 1 and 2 summarize the estimation results both for the 1957-1976 periods and for the 1964-1976 period. Figures 3 to 6, which will be seen later, show the performance of the model in relation with the observed JIP, SIP, AQJC, and SP variables for the 1957-1976 period. ${ }^{24}$ The equations are separately estimated with the ordinary least squares method. The overall results are basically satisfactory. First, when the regression coefficients are assumed to have a particular sign, they do in fact have that sign. Second, the $R^{2}$ statistics range from .620 to .907 when we deal with the 1964-1976 period. When we deal with the 1957-1976 period, two of the $R^{2}$ s become fairly small and in the case of the JIP equation the $R^{2}$ decreases to .115 and in the case of the SIP equation the $R^{2}$ decreases to .306 . However, except for the 1959-1961 period, the fits between the observed and estimated values are fairly good. ${ }^{25}$ In light of these facts, we have presented the results both for the 1957-1976 and 1964-1976 periods. (It is definitely not because we have wanted to purge "unfriendly" observations.) ${ }^{26}$ Third, the Durbin-Watson statistics show fairly

\footnotetext{
24 It must be noted that the JIP, SIP, and SP equations do not produce the estimated values of 1962 and 1963 because we have to exclude the 1962 and 1963 values. The 1962 policy intervention changed the definition of the regulated areas and thus the equations which encompass the pre-1962 and post-1962 years cannot include the 1962 and 1963 values due to the inclusion of two-year lagged variables.

${ }_{25}$ When we look at the observed values of the JIP and SIP in Figures 3 and 4, we are not too discouraged by the two low $R^{2}$ s for the 1957-1976 period. There are some reasons for them. First, the Japanese initial proposal of 1959 was more than 150,000 metric tons, which was "too high" when compared to the Soviet initial proposal of 1959 , which was 50,000 metric tons. Second, the Soviet initial proposals did not change at all during the 1959-1961 period, perhaps in an attempt to make Japan aware of the Soviet message not to make too high a proposal on the Japanese side. We can do nothing about these facts and the two low $R^{2} s$ for the 1957-1976 period do not make the analysis particularly less strong.

${ }^{26}$ The problem here is posed largely by a small number of observations, which is inherent in the research design. We could have included another (probably dummy) variable to account for this
} 
Table 1: Estimated results of the four equations (the 1957-1976 period) and predictive performance for the 1977 negotiation outcomes (thousand metric tons)

\begin{tabular}{|c|c|c|c|c|c|}
\hline 1957-1976 & & JIP, & SIP. & AQJC, & SP. \\
\hline 1 & & 118.97152 & 16.56415 & 15.11604 & 25.15526 \\
\hline AQPR, & & $\begin{array}{r}-.00180 \\
(.00133)\end{array}$ & & & \\
\hline$\overline{\mathrm{AQJC}} \mathrm{C}_{t-2}$ & & & $\begin{array}{l}1.10534 \\
(.46547)^{*}\end{array}$ & & \\
\hline $\mathrm{TC}_{t .2}$ & & & $\begin{array}{r}-.29428 \\
(.15117)\end{array}$ & & \\
\hline JIP. & & & & $\begin{array}{c}.25972 \\
(.04448)^{*}\end{array}$ & \\
\hline SIP. & & & & $\begin{array}{l}.63380 \\
(.05585)^{*}\end{array}$ & \\
\hline $\mathrm{SC}_{t-2}$ & & & & & $\begin{array}{c}.56388 \\
(.05723)^{*}\end{array}$ \\
\hline $\operatorname{DJCSC}_{t-2}$ & & & & & $\begin{array}{c}.29988 \\
(.15114)^{*}\end{array}$ \\
\hline $\mathbf{R}^{2}$ & & .11514 & .30647 & .93220 & .89321 \\
\hline$\overline{\mathbf{R}^{2}}$ & & .05193 & .19977 & .92422 & .87679 \\
\hline D.W. & & 1.65304 & 1.44237 & 2.65659 & 2.70117 \\
\hline Observed Value & $\mathbf{A}$ & 87.0 & 57.0 & 62.0 & $-* *$ \\
\hline Predicted Value & B & 91.3 & 66.2 & 80.8 & 74.2 \\
\hline Adjusted Predicted Value & $\mathrm{C}$ & 91.3 & 48.2 & 62.8 & - \\
\hline Difference & $\mathrm{C}-\mathrm{A}$ & 4.3 & -8.8 & .8 & - \\
\hline
\end{tabular}

Numbers in parentheses are standard errors.

* Significant at the .05 level.

** SP was not revealed in the 1977 negotiations. 
Table 2.: Estimated results of the four equations (the 1964-1976 period) and predictive performance for the 1977 negotiation outcomes (thousand metric tons)

\begin{tabular}{|c|c|c|c|c|c|}
\hline $1964-1976$ & & JIP, & SIP, & $\mathrm{AQJC}_{\boldsymbol{t}}$ & SP. \\
\hline 1 & & 131.08881 & .21468 & 8.71920 & 12.83189 \\
\hline$\overline{\mathrm{AQPR}}$ & & $\begin{array}{c}-.00299 \\
(.00066)^{*}\end{array}$ & & & \\
\hline $\mathrm{AQJC}_{1-2}$ & & & $\begin{array}{c}.83267 \\
(.32549)^{*}\end{array}$ & & \\
\hline$\overline{\mathrm{TC}_{t-2}}$ & & & $\begin{array}{r}-.00159 \\
(.11996)\end{array}$ & & \\
\hline JIP. & & & & $\begin{array}{c}.58943 \\
(.17634)^{*}\end{array}$ & \\
\hline$\overline{\text { SIP, }}$ & & & & $\begin{array}{c}.31024 \\
(.15894) \\
\end{array}$ & \\
\hline $\mathrm{SC}_{\mathrm{t-2}}$ & & & & & $\begin{array}{c}.82103 \\
(.15114)^{*}\end{array}$ \\
\hline DJCSC $_{t-2}$ & & & & & $\begin{array}{c}.08103 \\
(.14462)\end{array}$ \\
\hline$\overline{R^{2}}$ & & .64947 & .61984 & .87284 & .90692 \\
\hline$\overline{\overline{\mathrm{R}}^{2}}$ & & .61760 & .54381 & .84741 & .88830 \\
\hline D.W. & & 1.88100 & 2.65703 & 2.53163 & 2.28430 \\
\hline Observed Value & $\mathbf{A}$ & 87.0 & 57.0 & 62.0 & $-^{* *}$ \\
\hline Predicted Value & B & 85.1 & 75.7 & 77.7 & 78.1 \\
\hline Adjusted Predicted Value & $\mathrm{C}$ & 85.1 & 57.7 & 59.7 & $-* *$ \\
\hline Difference & $\mathbf{C}-\mathbf{A}$ & -1.9 & .7 & -2.3 & - \\
\hline
\end{tabular}

Numbers in parentheses are standard errors.

* Significant at the .05 level.

** SP was not revealed in the 1977 negotiations. 
satisfactory values ranging from 1.44 to 2.70 . Although the Durbin-Watson statistics by themselves cannot prove or disprove the absence of a serial correlation, these values do suggest that a serial correlation is not a serious problem in these equations. ${ }^{27}$ Fourth, the residual plots of the equations seem to show no clearly discernible systematic components outside of perhaps the JIP equation for the 1957-1976 period. Examination of the residual plots for the JIP equation for the 1957-1976 period shows the weak but discernible tendency that the higher the values of the dependent variable, the higher the absolute values of the residuals. If we look at Figure 3, however, it is immediately clear that the first three years, 1959-1961, are those which cause this phenomenon. Besides these years, there are no problems with residual plots. ${ }^{28}$ Fifth, F-statistics show that 71.4 percent of the regression coefficients for the 1957-1976 period are statistically significant at the 5 percent level. In sum, 64.3 percent of the regression coefficients reported in Tables 1 and 2 are statistically significant at the 5 percent level (those with asterisks in Tables 1 and 2). Sixth, perusal of outliers indicates that most of the outliers are concentrated in the first three years, i.e., 1959-61. All this seems to demonstrate that the overall performance of these equations is fairly good, although we do not deny that some slightly discouraging factors are not entirely absent. They are largely inherent in the research design itself where the number of observations is small. This is a situation with which social scientists too often have to live and the limitations are not taken to be so severe as to vitiate the analysis. In other words, the theoretical framework that we have chosen for the salmon catch negotiations' model has proved its basic correspondence with the empirical facts. Figures 3 to 6 present this information graphically.

The "predicted" values for the dependent variables for 1977 will be computed in order to further substantiate the following two points: 1) the overall validity of the model; and 2) the continuous presence of most of the structural components of the Soviet-Japanese salmon catch negotiations in 1977. We have predicted the 1977 values by applying the observed inde-

\footnotetext{
"anomaly" of the 1959-1961 period. However, this has not been done, in part because the number of observations of this period is only three. If we have a two-year lag term in an equation, when the number of observations for the whole period (sixteen or thirteen) is already very small, the degree of freedom is even further reduced. There is no point in introducing another variable into the equation if it is not certain that the variable is very powerful. When it is a dummy variable, that variable does not contribute to a better explanation of the dependent variable even if its introduction makes the results look better. Also it has not been done because we have wanted to keep the model as simple as possible. Thus the problem of the two low $\mathbf{R}^{2} \mathrm{~s}$ is not so severe as to vitiate the analysis.

${ }^{27}$ As for the problem of how to deal with serial correlation in a time series analysis, see, for example, P. Rao and R. L. Miller, Applied Econometrics (Belmont, California: Wadsworth, 1971); and D. A. Hibbs, Jr., "Problems of Statistical Estimation and Causal Inference in Time-Series Regression Models," in Sociological Methodology 1973-1974, H. L. Costner, ed. (San Francisco: Jossey-Bass, 1974), pp. 252-308.

${ }^{28}$ For the same reasons mentioned in footnote 26 we have not attempted to "save" this somewhat slightly discouraging phenomenon. The problem is inherent in the research design and the resulting problem is not so severe as to vitiate the analysis.
} 
Figure 3: The Japanese initial proposal for the Japanese catch (the 1957-1976 period)

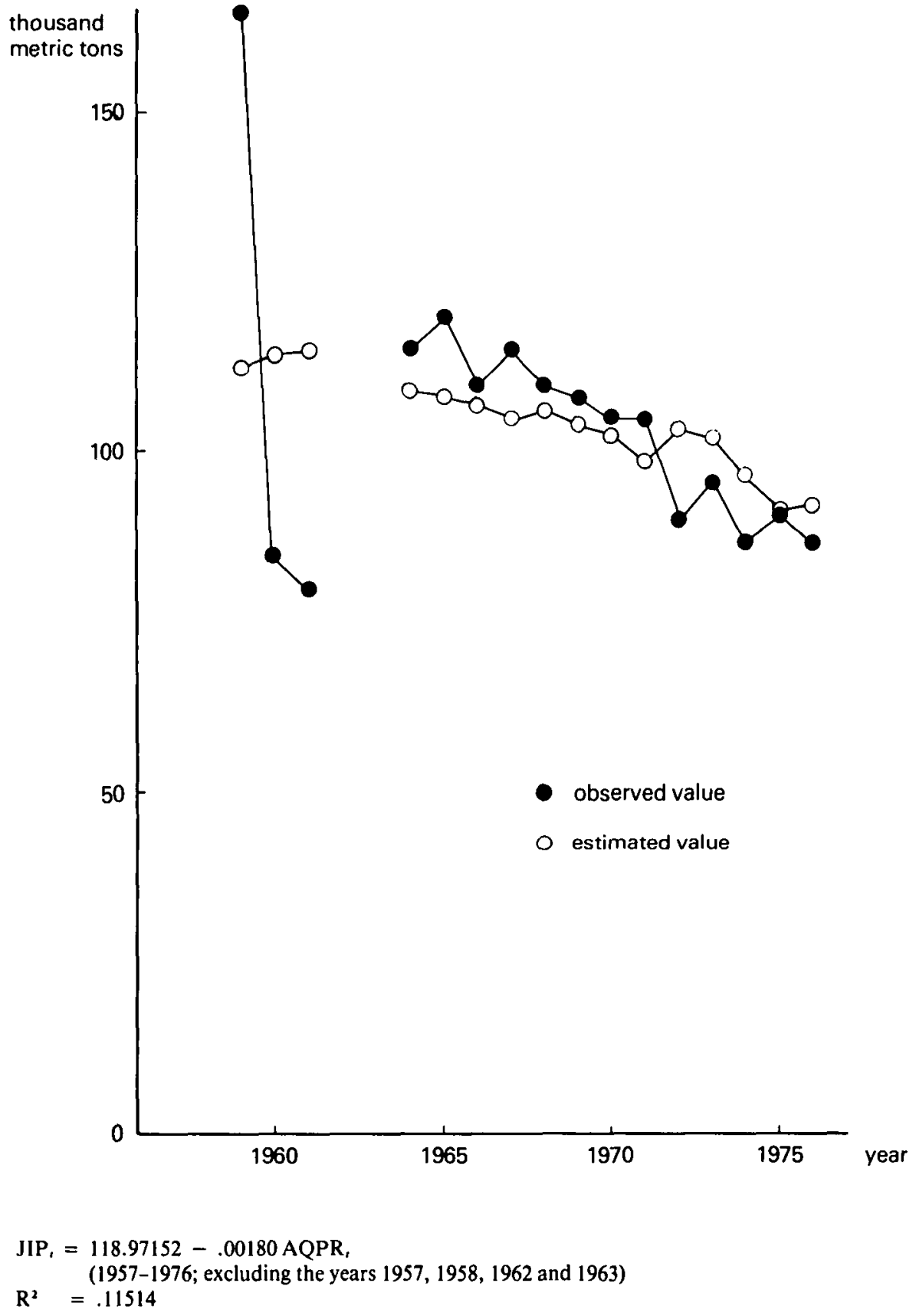


Figure 4: The Soviet initial proposal for the Japanese catch (the 1957-1976 period)

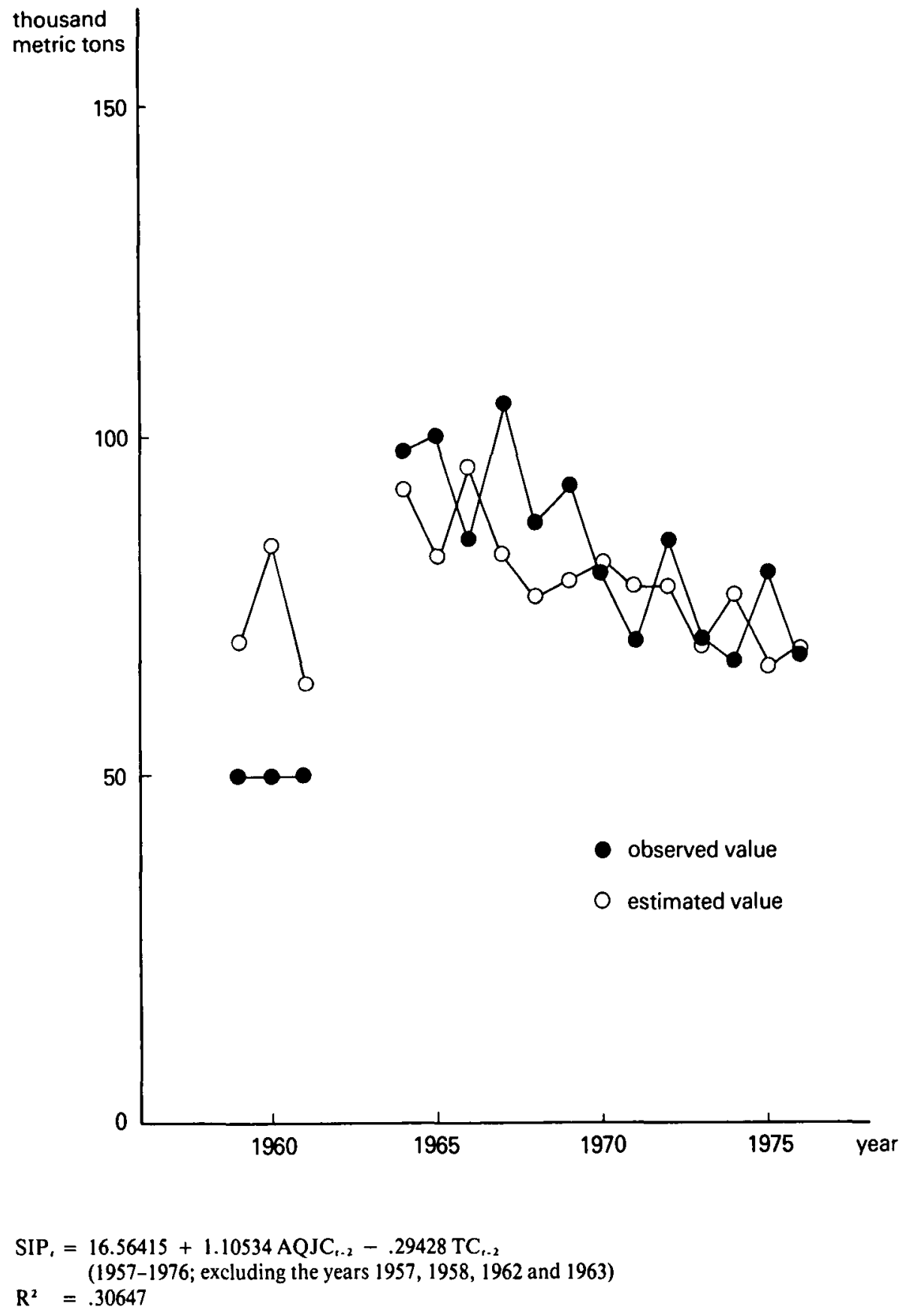


Figure 5: The agreed quota for the Japanese catch (the 1957-1976 period)

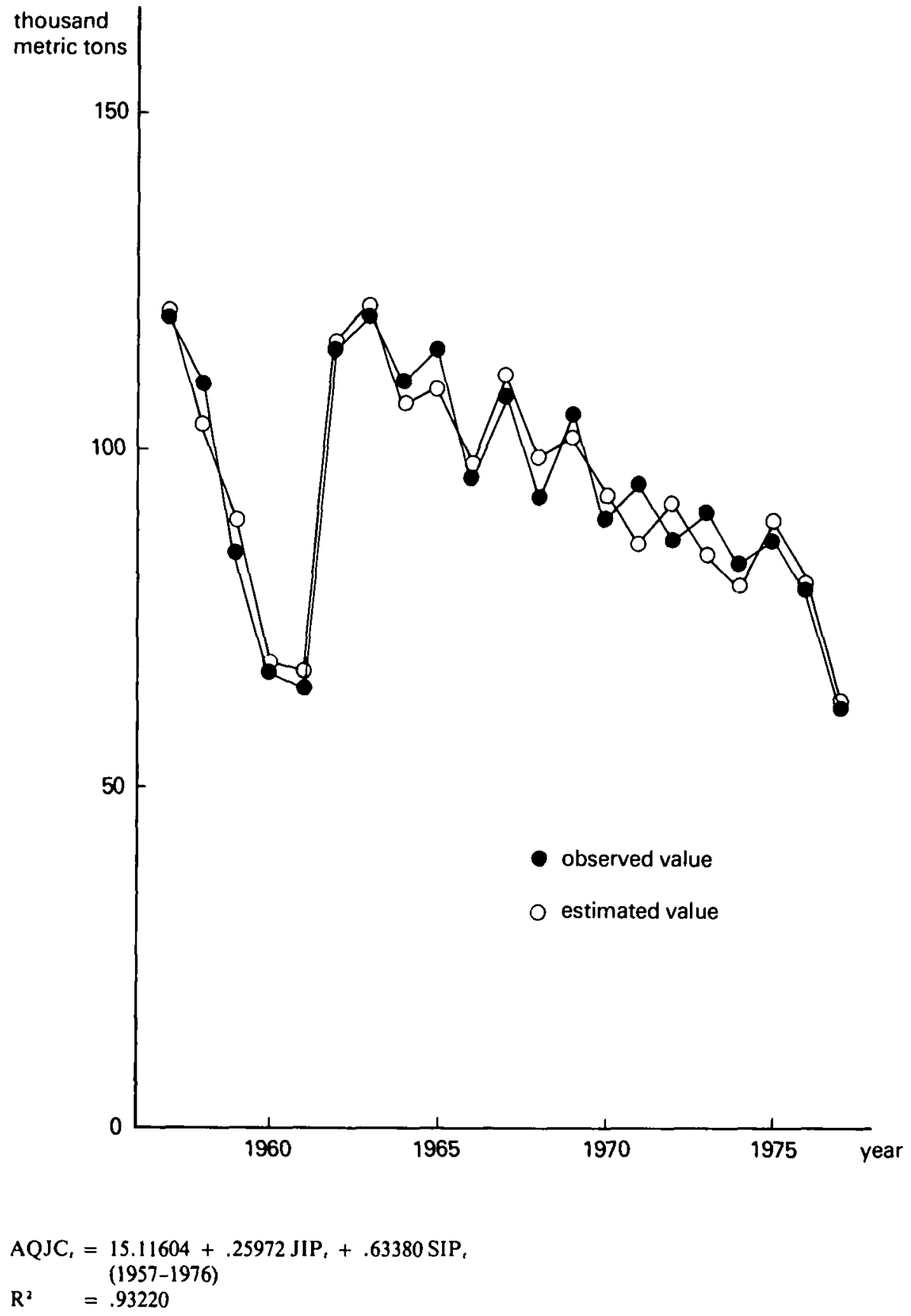


Figure 6: The Soviet catch plan (the 1957-1976 period)

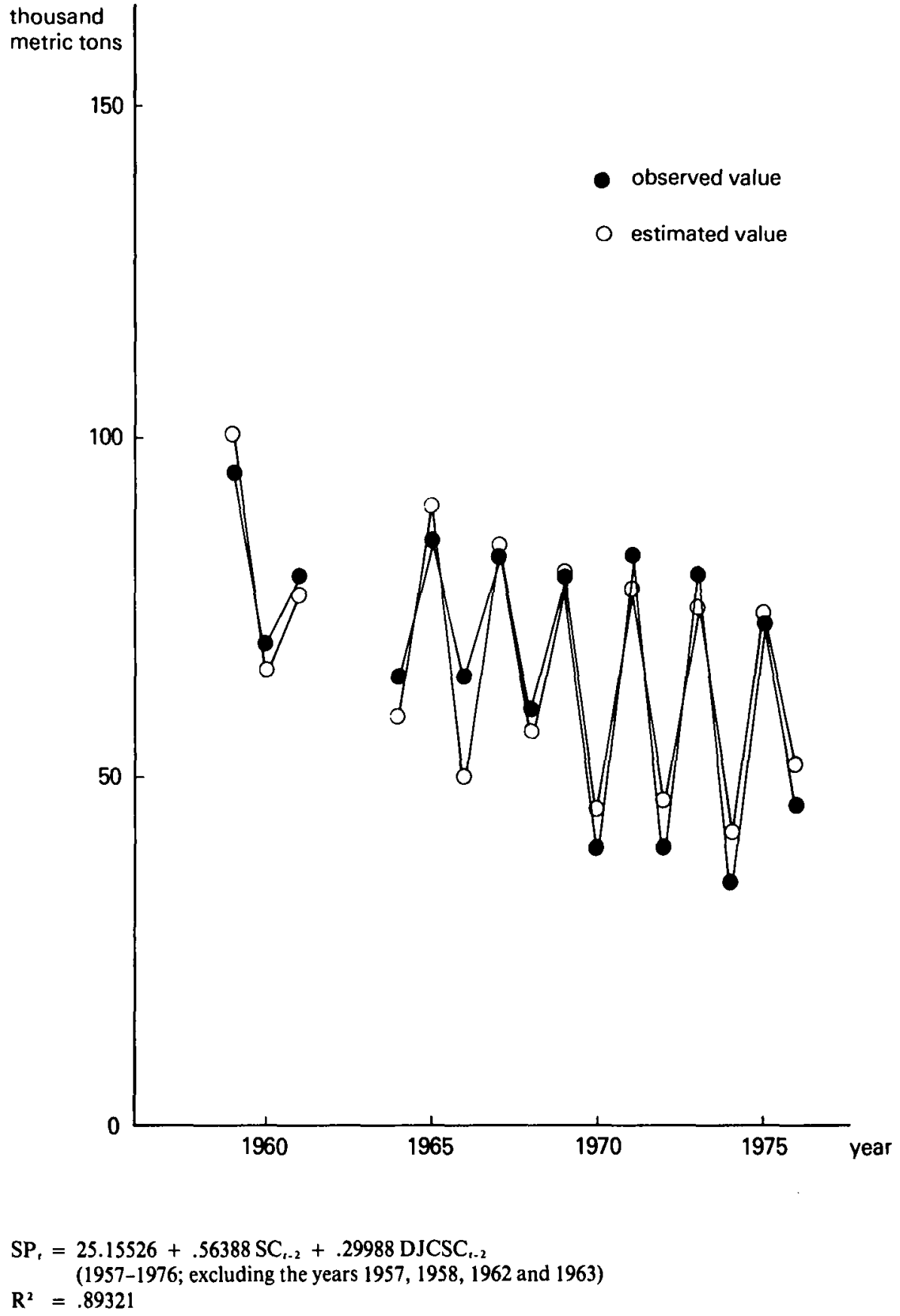


pendent variables of either 1975 or 1976 or 1977 values of the independent variables, depending on a particular time lag of each variable, to the estimated model structure. The results as summarized in the lower parts of Tables 1 and 2 demonstrate that the adjusted "predicted" values can be approximated to the actual values. The adjustment was necessitated by the Soviet ban of salmon catch within its 200 -mile zone. We subtracted 18,000 metric tons which is generally estimated as the amount of the Japanese salmon catch within the Soviet 200-mile zone. ${ }^{29}$ In other words, the quotas for 1977 apply only to the areas outside the Soviet 200 -mile zone in contrast to the previous quotas. The difference between the actual values and adjusted "predicted" values range from 700 metric tons to 2,300 metric tons in the case of the 1964-1976 models, while it ranges from 800 metric tons to 8,800 metric tons in the case of the 1957-1976 models. In short, the predictive performance is basically good. However, the following further observations must be made. The predictive performance of the 1964-1976 models is better than that of the 1957-1976 models except for the $\mathrm{AQJC}_{\mathrm{t}}$ equation. This can be explained by the trial-and-error phenomenon of the first few years. And the predictive performance for the JIP, and SIP, equations is worse than that for the AQJC, equation. This makes sense when we realize that the initial proposal equations might be somewhat contaminated by exogenous variables, which are presumed to be omitted, while the AQJC equation is accounted for largely by variables endogenous to the negotiations. Important among them might be the shifts of the political and economic factors within and outside each country and the differences in bargaining strategies, neither of which have been incorporated into our models. ${ }^{30}$

The good predictive performance seems to demonstrate that, in spite of the drift toward the enclosure of the oceans, most of the structural components of the Soviet-Japanese salmon catch negotiations have not been altered. The asymmetry of commitment between the Soviet Union and Japan as well as the commitment by the Soviet Union and Japan to the principle of keeping up with the maximum sustainable yield have not been fundamentally transformed. Both nations were committed to the organizational task of defining the maximum sustainable yield. The Soviet declaration of 200 -mile jurisdiction in late 1976 has meant that a large portion of the regulated area for the salmon catch has come under the Soviets' exclusive control and that Japan is not allowed to catch fish there unless otherwise agreed upon. However, the same commitment by both was retained in the area outside the Soviets' exclusive control. It is true that the isolated treatment of the technical salmon catch quota issue was conspicuously absent in the early sessions of the 1977

\footnotetext{
${ }^{29}$ On this figure, both newspaper accounts and a Fishery Agency official whom the first author of this paper interviewed in 1977 concurred.

${ }^{30}$ As for an interesting study of Japanese negotiating style, drawing from the pre-World War II Japanese negotiations, see M. Blaker, Japanese International Negotiating Style (New York: Columbia University Press, 1977).
} 
negotiations. The technical fishery issue became linked with a most sensitive and explosive issue, the territorial problem between the Soviet Union and Japan. The U.S., Canadian, and EEC declarations of 200-mile jurisdictions in early 1976 precipitated a declaration to the same effect by the Soviet Union later in 1976. In reaction, the Japanese Diet, in 1977, passed the 200-mile jurisdiction bill while the negotiations were going on, thus demonstrating its resolve that Japan's claim to the disputed Southern Kurile Islands be explicit against the unilateral Soviet declaration of its sovereignty over these islands. Consequently, the linkage between the fishery and territorial issues enormously complicated and prolonged the negotiations. The Japanese government effectively silenced the discontented fishermen, who were eclipsed by the nationwide anti-Soviet, nationalistic, irredentist upsurge which was the response to the two alternatives the government posed at the height of the difficulty of the negotiations, i.e., fish or territory. And after this manipulation of public opinion the government came to what the Soviet Union called a "pragmatic, bureaucratic, business-like approach" to the negotiations, leaving "high political" issues, i.e. terms of new fishery agreements which would replace the Convention of 1956, to the negotiations which were to be held later in 1977 and thereafter. Thus, when the salmon catch quota of 1977 was agreed upon by Japan and the Soviet Union in late spring 1977, the negotiations in the Commission only dealt with "low political" issues. In other words, at the end of the spring negotiations of 1977 the quota issue was isolated from "high political" issues. ${ }^{31}$ The relative independence of the Commission was partially destroyed by the above-described politicization. However, for the same reason as the one we have just explained, the Commission's relative independence was retained at the final phase of the negotiations, since "high political" issues were to be dealt with later in other separate negotiations. The stability of the negotiators was also partially impaired by this politicization. But again, for the same reason, the stability and continuity of the negotiators were basically retained at the last phase of the quota negotiations. Thus, it must be emphasized that as far as salmon catch quota negotiations-as distinguished from more "high political" negotiations on new fishery agreements replacing the one concluded in 1956-are concerned, the basic structural components did not change very much. Internal mechanisms for determining the initial proposals, the Japanese quota, and the Soviet plan did not undergo fundamental changes. Rather they remained more or less the same. The predictive performance of the structural equation model

${ }^{31}$ See the Nihon Keizai Shimbun or any other major Japanese newspapers from December 1976 to August 1977 for the day-to-day accounts of the sequence of the 1977 negotiations. See also Naya Masatsugu, "Ukemi gaiko no kozo: Nihon no kaiyo seisaku tenkan o megutte" (The Structure of a Passive Diplomacy: The Case of Japan's Changing Ocean Policy), a graduate seminar paper, Sophia University, Tokyo, 1977; and T. Inoguchi and N. Miyatake, "The Politics of Decrementalism: The Case of Soviet-Japanese Salmon Catch Negotiations, 1957-1977,", Behavioral Science 23 (November 1978): 457-469. 
for the proposals, the Japanese quota, and the Soviet plan substantiates this assertion.

\section{Conclusions}

Having adopted a somewhat unorthodox approach to the study of negotiation, we have attempted to show that the quasi-budgeting framework can be fruitfully employed for the study of negotiation. We have attempted to show, largely through examples, that if certain conditions are met, various negotiations can be submitted to an empirically testable formal analysis.

Our estimation results have been demonstrated to be fairly strong, indicating that our perspective is a powerful way of looking at such a phenomenon. Although the results are not without somewhat slightly discouraging "anomalies" such as the low $\mathbf{R}^{2}$ and the possible presence of a serial correlation for the JIP equation (1957-1976), most of the $R^{2} s$ are generally very high except for the JIP and SIP equation (1957-1976); all the regression coefficients have "right" signs; about two-thirds of the regression coefficients are statistically significant at the 5 percent level; Durbin-Watson statistics are around 1.4 to 2.7; and residual plots look fine with perhaps the exception of the above-mentioned JIP equation (1957-1976). In short, our structural equations model, which derives insights from the two budgeting theories, has been demonstrated to be basically correct in the context of the Soviet-Japanese salmon catch negotiations. Although we are not incognizant of alternative explanations, we have shown that the quasi-budgeting explanation is one strong way of explaining the phenomenon.

Our case has been further strengthened by the good predictive performance of our model. We have used the estimated parameters on the basis of the 1957-1976 and 1964-1976 data sets to "predict" the 1977 negotiations with very good results: when the observed values range from 57-87,000 metric tons, the differences between the observed values and our adjusted "predicted" values are as small as 700 to 8,800 metric tons. In short, the results are striking. All the more so because no study of this kind has been done before.

More substantively, we have shown that, despite the periodical "noise" and "fuss" generated by the fishery issues in the Soviet-Japanese relations over the last twenty years or so, both countries have learned to encapsulate to a certain extent, potentially intense conflicts of interest in this aspect of the bilateral relationship. Although the outcome of the 1978 negotiations, which are not based on the 1956 Convention, is clearly beyond our present scope, it might be useful to add a few words about it. In the 1978 negotiations the spirit of joint preservation and exploitation of the open sea was dashed and almost entirely replaced by the assertion of the hegemonial coastal state's rights of controlling all the salmon stock belonging to the Soviet "mother" rivers. Thus, the spirit underlying the Soviet-Japanese fishery relationship has 
become very similar to the fishery relationship between the United States and Canada, on the one hand, and Japan, on the other hand, whose pattern was set by the International North Pacific Fisheries Convention in 1952. More specifically, the new regulations include: 1 ) another new large fishing ban area, north of $44^{\circ}$ north latitude, east of $170^{\circ}$ west longitude, surrounded by the 200mile zones of the United States and the Soviet Union, has been defined; 2) the agreed quota for the 1978 Japanese catch is 42,500 metric tons; 3) Japan is to pay the Soviet Union 1.7 billion yen for the 1978 salmon catch in the area; and 4) annual negotiations are prescribed. (See, for instance, Asahi Shimbun, 21 April 1978.) Since the spirit of the Soviet-Japanese fishery relationship and the entire institutional relationship have changed, the formula for "predicting" negotiation outcomes cannot be applied to the 1978 case.

Having shown all this, it is still safe to conclude that our argument is both conceptually powerful and methodologically feasible in the study of various international negotiations. The present research has been formulated in part to provide one example for those interested in formally analyzing such phenomena. 